\title{
Maritime English Languages
}

\section{Sanela Kovačević Pejaković}

\section{Doi:10.5901/jesr.2014.v4n4p512}

\author{
Fakultet za pomorstvo, Kotor
} Email: sanelap@ac.me

\begin{abstract}
This paper implies the restricted aspect of a complex system such as English for specific purpose in the nautical education and profession. The sophisticated system of the maritime English makes it a plain instrument of communication. On one hand, there is the restricted feature of English maritime language. On the other hand the creativity of maritime registers and subregisters makes the linguistic diversity more distinctive and research worthy. The levels are numerous and a specific situation requires a specific register or sub-register. Since the maritime language is further subdivided into registers and subregisters, we can make a distinction between maritime language and maritime languages. The complexity of the nautical register makes learning, that is acquisition very difficult. One should firstly learn maritime terms in his own mother tongue and then move into the maritime English world. We have tried to look into certain subregisters within Standard Marine Communication Phrases (SMCP) by pointing out the main characteristics. "Seaspeak" is a vital instrument of communication on board a ship. The importance of English language has always been emphasized, especially the importance of the standardized maritime phrases used in vessel-to-vessel and vessel-to-port communication. We can conclude that maritime English is a restricted language which is characterized by a great many specific features on the phonological, morphological, lexical and syntaxical level. These particularities are the most obvious on the lexical level, for it implies maritime terms. This level is also under the greatest influence of the real world, for it reflects the life at sea.
\end{abstract}

Keywords: linguistic, restricted language, registers, GMDSS, pragmatics, seaspeak, specific purpose, ship, sail, rudder, derrick, VHF-equipment, needs analysis. 